\title{
Development of Non-reactive F-Free Mold Fluxes for High Aluminum Steels: Non-isothermal Crystallization Kinetics for Devitrification
}

\author{
QIFENG SHU, QIANGQI LI, SAMUEL LUCAS SANTOS MEDEIROS, \\ and JEFERSON LEANDRO KLUG
}

It is necessary to study crystallization from glass (devitrification) for non-reactive F-free $\mathrm{CaO}-\mathrm{Al}_{2} \mathrm{O}_{3}$ based mold fluxes; this is especially important for the development of mold fluxes for continuous casting of high aluminum steels. To the knowledge of the authors, there is no report in the literature regarding devitrification of F-free mold fluxes based on the $\mathrm{CaO}-\mathrm{Al}_{2} \mathrm{O}_{3}-\mathrm{B}_{2} \mathrm{O}_{3}-\mathrm{Na}_{2} \mathrm{O}-\mathrm{Li}_{2} \mathrm{O}$ system. Therefore, crystallization kinetics for particular compositions in this system, with different $\mathrm{w}(\mathrm{CaO}) / \mathrm{w}\left(\mathrm{Al}_{2} \mathrm{O}_{3}\right)$ ratios, was investigated by Differential Scanning Calorimeter, Field-Emission Environmental Scanning Electron Microscopy / Energy Dispersive Spectroscopy, and X-ray Diffraction techniques. The first crystal, which precipitates during heating from glass, is $\mathrm{Ca}_{12} \mathrm{Al}_{14} \mathrm{O}_{33}$, followed by $\mathrm{CaO}$. For the first crystal, which precipitates as plate-like (2-dimensional), it was found that, when using the Matusita-Sakka model, agreement between the calculated Avrami parameters and the micrographs obtained from electron microscope was reached. In the same way, agreement was found for the second event- $\mathrm{CaO}$ precipitation-which grows 2-dimensionally or 3-dimensionally, depending on the $\mathrm{w}(\mathrm{CaO}) / \mathrm{w}\left(\mathrm{Al}_{2} \mathrm{O}_{3}\right)$ ratio. The most important event (in terms of energy liberated and amount of crystals) is $\mathrm{Ca}_{12} \mathrm{Al}_{14} \mathrm{O}_{33}$ precipitation. For this event, the effective activation energy for crystallization, $E_{\mathrm{G}}$, decreases with the increase of $\mathrm{w}(\mathrm{CaO}) /$ $\mathrm{w}\left(\mathrm{Al}_{2} \mathrm{O}_{3}\right)$ ratio. The activation energy for crystallization reflects the energy barrier for crystallization. Thus, it can be concluded that mold fluxes crystallization during heating is enhanced when increasing the $\mathrm{w}(\mathrm{CaO}) / \mathrm{w}\left(\mathrm{Al}_{2} \mathrm{O}_{3}\right)$ ratio, for constant contents of $\mathrm{B}_{2} \mathrm{O}_{3}, \mathrm{Na}_{2} \mathrm{O}$, and $\mathrm{Li}_{2} \mathrm{O}$.

https://doi.org/10.1007/s11663-020-01838-4

(c) The Author(s) 2020

\section{INTRODUCTION}

CONSIDERING the development of non-reactive F-free mold fluxes for the continuous casting of high aluminum steels, it is imperative to understand their crystallization behavior in the mold, since control of horizontal heat transfer is related to crystallization tendency. An inappropriate control of heat transfer in

QIFENG SHU is with the Research Unit of Process Metallurgy, University of Oulu, 90014 Oulu, Finland and also with the School of Metallurgical and Ecological Engineering, University of Science and Technology, Beijing, Beijing 100083, China. Contact emails: shuqifeng@gmail.com, qifeng.shu@oulu.fi QIANGQI LI is with the School of Metallurgical and Ecological Engineering, University of Science and Technology. SAMUEL LUCAS SANTOS MEDEIROS and JEFERSON LEANDRO KLUG are with the Postgraduate Program in Materials Science and Engineering, Federal University of Ceará, Fortaleza, Ceará, CEP 60440-554, Brazil.

Manuscript submitted July 17, 2019.

Article published online April 14, 2020. continuous casting process can result in breakout if heat transfer rate is too low, or longitudinal cracks if heat transfer rate is too high.

Mold fluxes play a crucial role in the continuous casting of defect-free steel products, providing appropriate heat transfer control, lubrication, thermal insulation, inclusion absorption, and oxidation prevention. ${ }^{[1]}$ It is well accepted that horizontal heat transfer rate can be controlled when controlling mold slag crystallization..$^{[2,3]}$

Transformation-induced plasticity (TRIP) steel has become a new representative of advanced high-strength steel for lightweight automotive applications. During continuous casting of high aluminum steels using traditional $\mathrm{CaO}-\mathrm{SiO}_{2}-\mathrm{CaF}_{2}$ based mold fluxes, operational issues and quality problems arise due to the steel/ slag interfacial reaction: $\mathrm{Al}+\left(\mathrm{SiO}_{2}\right)=\mathrm{Si}+\left(\mathrm{Al}_{2} \mathrm{O}_{3}\right)$. This reaction is fast and leads to increase of $\mathrm{Al}_{2} \mathrm{O}_{3}$ content in the mold slag, causing problems such as massive formation of slag rim, poor lubrication, and uneven horizontal heat transfer. To deal with this 
question, a possibility is to remove $\mathrm{SiO}_{2}$ from mold flux, which would result in "non-reactive" mold fluxes, i.e., the reaction could not happen. ${ }^{[4-6]}$

Another industry demand related to mold fluxes is the need for eliminating fluorine from their composition. Volatile and water-soluble fluorine compounds are formed when using traditional $\mathrm{CaO}-\mathrm{SiO}_{2}-\mathrm{CaF}_{2}$-based mold fluxes, causing corrosion of casting facilities and environmental pollution. ${ }^{[7-10]}$ Any potential substitute- $\mathrm{B}_{2} \mathrm{O}_{3}, \mathrm{Na}_{2} \mathrm{O}, \mathrm{Li}_{2} \mathrm{O}, \mathrm{TiO}_{2}$ - or a combination of them should play the same role as fluorine regarding the technological parameters viscosity, crystallization behavior, and characteristic temperatures got from heating microscope. ${ }^{[5]}$

In order to deal with these demands, in a previous study, several recipes of $\mathrm{F}$-free $\mathrm{CaO}-\mathrm{Al}_{2} \mathrm{O}_{3}$-based mold fluxes were proposed and evaluated. In this study, ${ }^{[5]}$ it was reported that, for some compositions in the $\mathrm{CaO}-\mathrm{Al}_{2} \mathrm{O}_{3}-\mathrm{B}_{2} \mathrm{O}_{3}-\mathrm{Na}_{2} \mathrm{O}-\mathrm{Li}_{2} \mathrm{O}$ system, the viscosity and melting temperature were close to traditional $\mathrm{CaO}$ $\mathrm{SiO}_{2}-\mathrm{CaF}_{2}$ mold fluxes. Besides, crystallization from mold slag was analyzed. The first crystal, which precipitates during continuous cooling, is $\mathrm{Ca}_{3} \mathrm{Al}_{2} \mathrm{O}_{6}$, followed by $\mathrm{LiAlO}_{2}$ and $\mathrm{Ca}_{3} \mathrm{~B}_{2} \mathrm{O}_{6}$. It was found that crystallization temperatures got from differential thermal analysis (DTA) decreases when increasing $\mathrm{B}_{2} \mathrm{O}_{3}$ and $\mathrm{Na}_{2} \mathrm{O}$

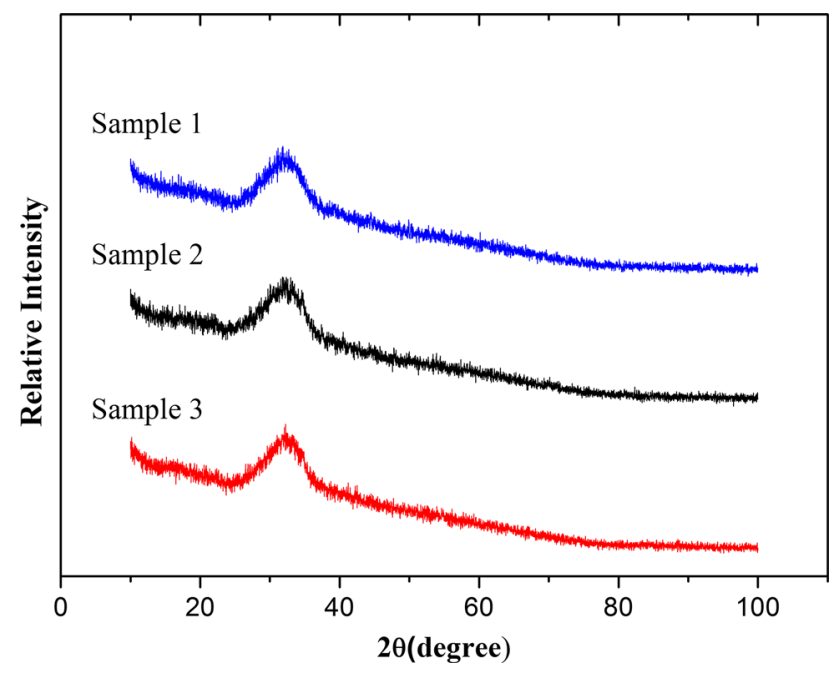

Fig. 1-X-ray diffraction pattern for Sample 1, 2, and 3. contents. This work concluded that some recipes in the $\mathrm{CaO}-\mathrm{Al}_{2} \mathrm{O}_{3}-\mathrm{B}_{2} \mathrm{O}_{3}-\mathrm{Na}_{2} \mathrm{O}-\mathrm{Li}_{2} \mathrm{O}$ system are potential substitutes for traditional mold powders. Due to their non-reactive behavior (no $\mathrm{SiO}_{2}$ ), these new fluorine-free mold fluxes could be applied for casting of high Al steels.

Regarding crystallization behavior for traditional fluorine-bearing mold powders, the crystallization of cuspidine from mold slag is thought to be the most effective way of exerting heat-transfer control. Although the mechanism of heat-transfer control via the crystallization of cuspidine has not yet been determined, two ideas have been proposed. An idea is that radiation heat flux decreases by scattering at the boundary between the crystalline and the liquid layers during crystallization from slag. Another idea is that the total heat flux decreases by the large thermal resistance of the air gap formed as a result of the solidification shrinkage of the solidified slag layer (which occurs due to crystallization from glass). In any case, the crystallization of cuspidine from mold slag has a great effect on heat-transfer control. $^{[11]}$ Besides crystallization from liquid slag, crystallization from glass is also relevant during continuous casting of steel. For the aforementioned work, ${ }^{[5]}$ crystallization from glass was not studied.

Crystallization from glass occurs during continuous casting of steel. The molten flux, which infiltrates between the water-cooled copper mold and the steel shell, solidifies and forms a solid layer, composed by a glassy part and a crystalline part. With time, the glassy fraction will inevitably absorb heat and then crystallization occurs, affecting the thickness of the solid layer and its surface roughness, exerting in this way strong influence on horizontal heat transfer and lubrication. ${ }^{[1-3]}$ Thus, it is necessary to study this phenomenon to get a better understanding on mold fluxes crystallization behavior.

Several techniques have been developed to study the crystallization behavior of mold fluxes, such as DTA. ${ }^{[12,13]}$ Differential Scanning Calorimetry (DSC), ${ }^{[14-16]}$ Single Hot Thermocouple Technique (SHTT), ${ }^{[17-19]}$ Double Hot Thermocouple Technique (DHTT) ${ }^{[17,20]}$ laser confocal microscopy, ${ }^{[21]}$ and others. $^{[22]}$ However, most of these studies were performed above mold flux liquidus temperature and therefore mainly dealt with crystallization from molten slag. Few papers are found for mold flux devitrification. ${ }^{[12,13,23]}$ The present authors investigated traditional

Table I. Elemental Chemical Composition for the Three Glassy Samples Produced in the Present Work

\begin{tabular}{|c|c|c|c|c|c|c|c|}
\hline \multirow[b]{2}{*}{ Sample } & \multirow[b]{2}{*}{$\mathrm{w}(\mathrm{CaO}) / \mathrm{w}\left(\mathrm{Al}_{2} \mathrm{O}_{3}\right)$} & & \multicolumn{5}{|c|}{ Composition (Wt Pct) } \\
\hline & & & $\mathrm{CaO}$ & $\mathrm{Al}_{2} \mathrm{O}_{3}$ & $\mathrm{~B}_{2} \mathrm{O}_{3}$ & $\mathrm{Na}_{2} \mathrm{O}$ & $\mathrm{Li}_{2} \mathrm{O}$ \\
\hline \multirow[t]{2}{*}{1} & 0.9 & nominal & 36.0 & 40.0 & 8.0 & 8.0 & 8.0 \\
\hline & & analyzed & 36.0 & 38.1 & 9.2 & 8.3 & 8.0 \\
\hline \multirow[t]{2}{*}{2} & 1.0 & nominal & 38.0 & 38.0 & 8.0 & 8.0 & 8.0 \\
\hline & & analyzed & 36.9 & 35.4 & 8.8 & 7.5 & 8.0 \\
\hline \multirow[t]{2}{*}{3} & 1.1 & nominal & 40.0 & 36.0 & 8.0 & 8.0 & 8.0 \\
\hline & & analyzed & 40.1 & 33.2 & 7.7 & 7.6 & 8.0 \\
\hline
\end{tabular}


glassy mold fluxes ${ }^{[13,24]}$ and glassy fluoride-free mold fluxes based on $\mathrm{CaO}-\mathrm{SiO}_{2}-\mathrm{TiO}_{2}-\mathrm{B}_{2} \mathrm{O}_{3}$ system using DTA. ${ }^{[25]}$ Regarding devitrification of fluorine-free mold fluxes based on the $\mathrm{CaO}-\mathrm{Al}_{2} \mathrm{O}_{3}-\mathrm{B}_{2} \mathrm{O}_{3}$ system, no report was found in the literature.

The present paper reports an investigation using DSC with multiple heating rates, considering non-isothermal crystallization kinetics for glassy fluorine-free mold fluxes in the $\mathrm{CaO}-\mathrm{Al}_{2} \mathrm{O}_{3}-\mathrm{B}_{2} \mathrm{O}_{3}-\mathrm{Na}_{2} \mathrm{O}-\mathrm{Li}_{2} \mathrm{O}$ system. Field-Emission Environmental Scanning Electron Microscope/Energy Dispersive Spectroscopy (FE-SEM/EDS) techniques were used to identify crystalline phases and observe the morphology of crystals. Crystallization mechanisms and activation energies for devitrification were determined for three mold flux samples, with the ratios $\mathrm{w}(\mathrm{CaO}) / \mathrm{w}\left(\mathrm{Al}_{2} \mathrm{O}_{3}\right) 0.9,1.0$, and 1.1 .

\section{EXPERIMENTAL}

\section{A. Sample Preparation}

Analytical grade $\mathrm{Al}_{2} \mathrm{O}_{3} \quad\left(>99\right.$ pct), $\mathrm{Na}_{2} \mathrm{CO}_{3}$ (>99.9 pct), $\mathrm{Li}_{2} \mathrm{CO}_{3}$ (>99.9 pct), $\mathrm{CaCO}_{3}$ (>99 pct), and $\mathrm{H}_{3} \mathrm{BO}_{3}$ (>99.95 pct) powders were employed as raw materials. $\mathrm{Na}_{2} \mathrm{CO}_{3}, \mathrm{Li}_{2} \mathrm{CO}_{3}$, and $\mathrm{H}_{3} \mathrm{BO}_{3}$ were adopted as sources for $\mathrm{Na}_{2} \mathrm{O}, \mathrm{Li}_{2} \mathrm{O}$, and $\mathrm{B}_{2} \mathrm{O}_{3}$, respectively. $\mathrm{CaCO}_{3}$ was held at $1323 \mathrm{~K}\left(1050{ }^{\circ} \mathrm{C}\right)$ overnight to produce $\mathrm{CaO}$ in a muffle furnace. $\mathrm{Na}_{2} \mathrm{CO}_{3}, \mathrm{Li}_{2} \mathrm{CO}_{3}$, and $\mathrm{Al}_{2} \mathrm{O}_{3}$ powders were calcined at $573 \mathrm{~K}$ to remove moisture. Raw materials were mixed in an agate mortar and held in a platinum crucible placed in a $\mathrm{MoSi}_{2}$ furnace at $1623 \mathrm{~K}\left(1350{ }^{\circ} \mathrm{C}\right)$ for 2 hours in air. Finally, the melts were quenched into water and glassy cullets were obtained. The quenched samples were pulverized. The amorphous state of the samples was verified by X-ray diffractometry (XRD), Figure 1 . The composition of glassy samples was analyzed by Electron Probe Micro-Analyzer (EPMA) and it can be seen in Table I. In this way, three samples with different $\mathrm{w}(\mathrm{CaO}) /$ $\mathrm{w}\left(\mathrm{Al}_{2} \mathrm{O}_{3}\right)$ ratio ranging from 0.9 to 1.1 were produced. Nominal contents of $\mathrm{B}_{2} \mathrm{O}_{3}, \mathrm{Na}_{2} \mathrm{O}$, and $\mathrm{Li}_{2} \mathrm{O}$ were maintained for all samples (8 wt pct).

\section{B. Thermal Analysis}

DSC runs were performed using a thermal analyzer STA 449 F3 Jupiter from the manufacturer Netzsch-Gerätebau $\mathrm{GmbH}$, with argon acting as purge gas at dynamic conditions. Calibration for the apparatus was performed using alfa- $\mathrm{Al}_{2} \mathrm{O}_{3}$ as the reference material, building a temperature calibration curve and a sensitivity calibration curve with pure substances. After calibration, the quenched samples were heated up to $1350{ }^{\circ} \mathrm{C}$ with different heating rates. Platinum crucibles with platinum lids were employed to minimize the loss of volatile substances. A new baseline was generated for each heating rate using an empty platinum crucible.
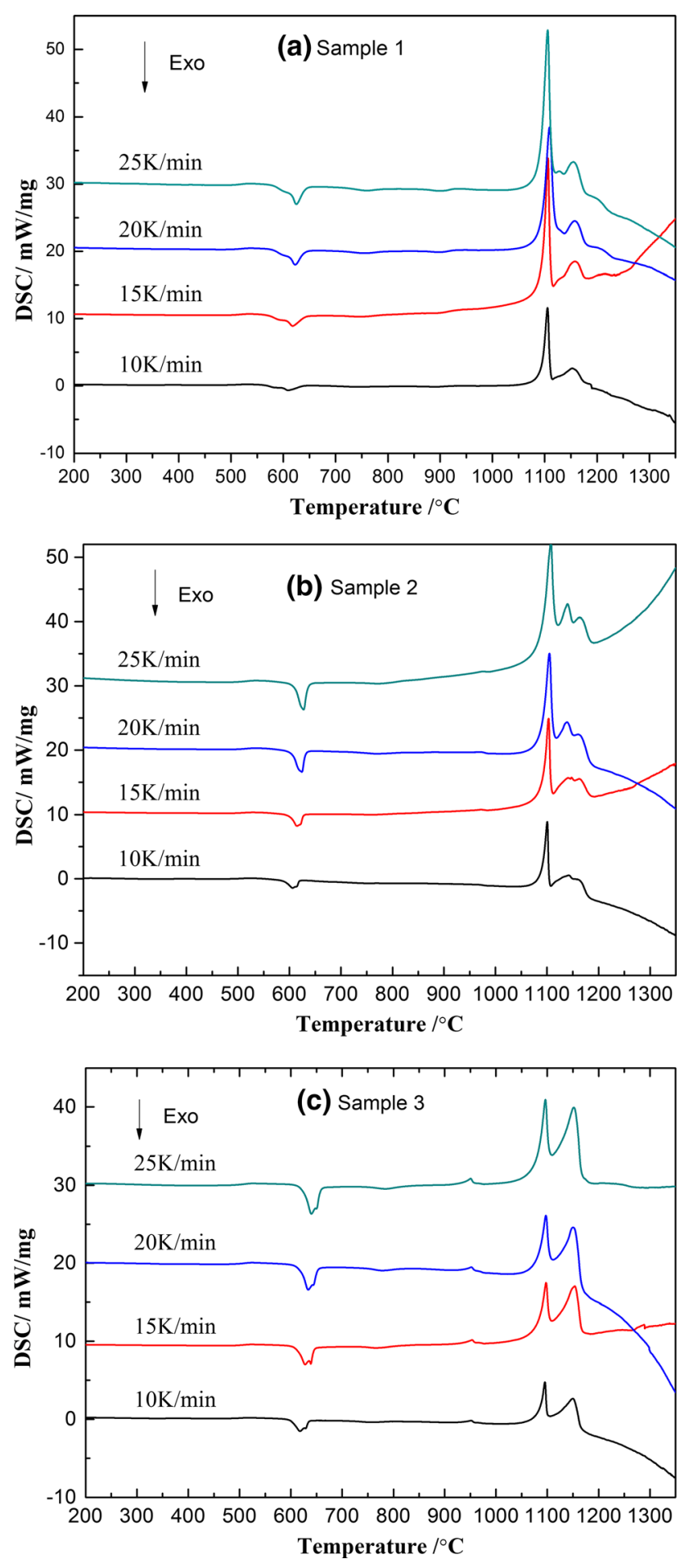

Fig. 2-DSC curves for Sample $1(a)$, Sample $2(b)$, and Sample 3 (c) at different heating rates.

\section{Phase Analysis}

Glassy samples were heated from room temperature to target temperatures at a rate of $5 \mathrm{~K} / \mathrm{min}$ in a muffle furnace and then quenched in water. The total heating time at the target temperature is approximately 4 hours. 
The composition and the morphology of crystallization products were identified by FE-SEM/EDS (Zeiss Merlin compact) with a working voltage of $15 \mathrm{kV}$.

\section{RESULTS AND DISCUSSION}

Figure 2 shows the DSC results for Sample 1, 2, and 3 at heating rates of $10,15,20$, and $25^{\circ} \mathrm{C} / \mathrm{min}$. The exothermic crystallization peak for any curve is actually the envelope for two overlapped peaks. This indicates that there are two successive exothermic events due to the crystallization of glass during heating.

A deconvolution process based on Lorenz functions was employed to separate the peaks, using the software OriginPro 8.5, as shown in Figure 3.

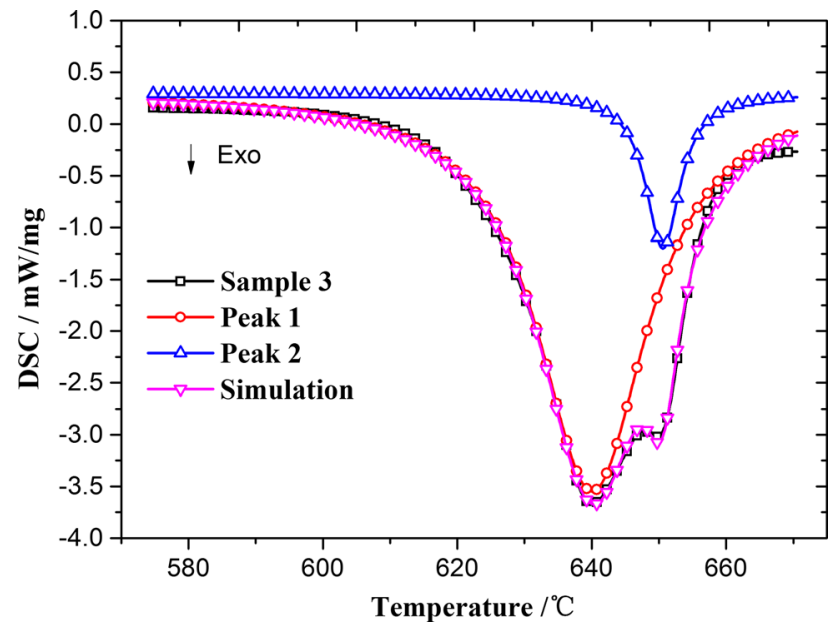

Fig. 3-Example of deconvolution using two Lorenz peaks (Sample 3 , heating rate $20 \mathrm{~K} / \mathrm{min}$ ).
Onset and peak temperatures for the heating rates 10 , 15,20 , and $25^{\circ} \mathrm{C} / \mathrm{min}$ for all samples, considering the first and the second crystallization events (peak 1 and peak 2), are shown in Table II. The higher the $\mathrm{w}(\mathrm{CaO}) /$ $\mathrm{w}\left(\mathrm{Al}_{2} \mathrm{O}_{3}\right)$ ratio is, the higher the onset and peak temperatures become, for both events.

The crystallization kinetics for glasses is determined by both the nucleation rate and the crystal growth rate. Since it takes time for nuclei to form and grow to a specific crystal size, the onset and peak crystallization temperatures increase at higher heating rate, according to Table II. This statement can be understood considering the schematic curves in Figure 4, which explains qualitatively crystallization from glassy state; it shows the nucleation rate and crystal growth rate curves as a function of temperature. The driving force for nucleation increases with decrease of temperature. On the contrary, the mobility of ions decreases with decrease of temperature. Therefore, the maximum for nucleation rate is at lower temperature. At $T_{1}$ in this figure, nucleation rate is high and crystal growth rate is low. On the other hand, the nucleation rate is low and crystal

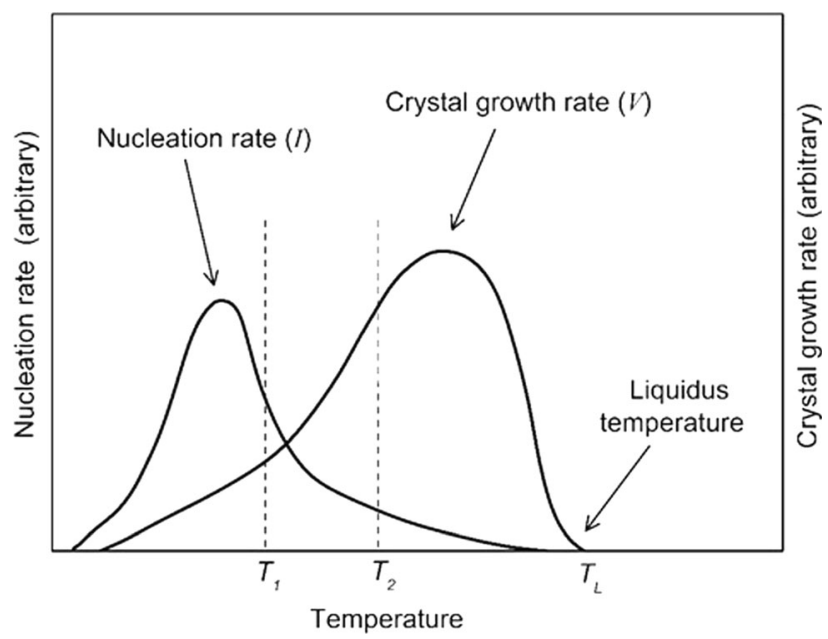

Fig. 4-Schematic curves of the nucleation rate and the crystal growth rate as a function of temperature.

Table II. Onset and Peak Temperature for the Heating Rates 10, 15, 20, and $25^{\circ} \mathrm{C} / \mathrm{min}$ for All Samples, Considering the First and The Second Crystallization Events (Peak 1 and Peak 2)

\begin{tabular}{|c|c|c|c|c|c|c|c|}
\hline \multirow[b]{2}{*}{ Sample } & \multirow[b]{2}{*}{$\mathrm{w}(\mathrm{CaO}) / \mathrm{w}\left(\mathrm{Al}_{2} \mathrm{O}_{3}\right)$} & & \multicolumn{5}{|c|}{ Heating Rate $\left({ }^{\circ} \mathrm{C} / \mathrm{min}\right)$} \\
\hline & & & & 10 & 15 & 20 & 25 \\
\hline \multirow[t]{4}{*}{1} & \multirow[t]{4}{*}{0.9} & \multirow[t]{2}{*}{ peak 1} & onset & 565 & 574 & 579 & 583 \\
\hline & & & peak & 581 & 591 & 596 & 601 \\
\hline & & \multirow[t]{2}{*}{ peak 2} & onset & 583 & 596 & 602 & 608 \\
\hline & & & peak & 611 & 619 & 623 & 625 \\
\hline \multirow[t]{4}{*}{2} & \multirow[t]{4}{*}{1.0} & \multirow[t]{2}{*}{ peak 1} & onset & 591 & 601 & 605 & 610 \\
\hline & & & peak & 605 & 612 & 619 & 628 \\
\hline & & \multirow[t]{2}{*}{ peak 2} & onset & 611 & 616 & 620 & 623 \\
\hline & & & peak & 614 & 620 & 626 & 628 \\
\hline \multirow[t]{4}{*}{3} & \multirow[t]{4}{*}{1.1} & \multirow[t]{2}{*}{ peak 1} & onset & 604 & 613 & 619 & 625 \\
\hline & & & peak & 617 & 627 & 633 & 640 \\
\hline & & \multirow[t]{2}{*}{ peak 2} & onset & 622 & 634 & 637 & 645 \\
\hline & & & peak & 628 & 638 & 644 & 650 \\
\hline
\end{tabular}


growth rate is high at $T_{2}{ }^{[23]}$ Thus, the higher the heating rate is, the more the onset and peak crystallization temperatures are, since there is less time for formation of nuclei and growth of crystals.

The FE-SEM micrographs for the samples heated at different temperatures are shown in Figure 5. Many $\mathrm{Ca}_{12} \mathrm{Al}_{14} \mathrm{O}_{33}$ crystals precipitated in all samples. At higher temperature, some $\mathrm{CaO}$ crystals also precipitated. XRD patterns for the samples heated at different temperatures are shown in Figure 6. The existence of $\mathrm{Ca}_{12} \mathrm{Al}_{14} \mathrm{O}_{33}$ and $\mathrm{CaO}$ crystals is verified by XRD patterns. There are extra phases of $\mathrm{LiAlO}_{2}$ found in
XRD patterns. The $\mathrm{LiAlO}_{2}$ phase was not found in FE-SEM analysis which could be due to the extreme small size of this phase. Since the DSC peaks during heating mainly reflect the crystal growth, the contribution of $\mathrm{LiAlO}_{2}$ phase on the DSC peak should be negligible. Therefore, the two overlapped DSC peaks are assigned to the crystallization of $\mathrm{Ca}_{12} \mathrm{Al}_{14} \mathrm{O}_{33}$ - first crystal during heating, followed by $\mathrm{CaO}$.

The relative crystallinity values $\alpha_{T}$ for one crystallization event can be obtained as a function of temperature (T) from DSC curves through the following equation $^{[15,16]}$ :

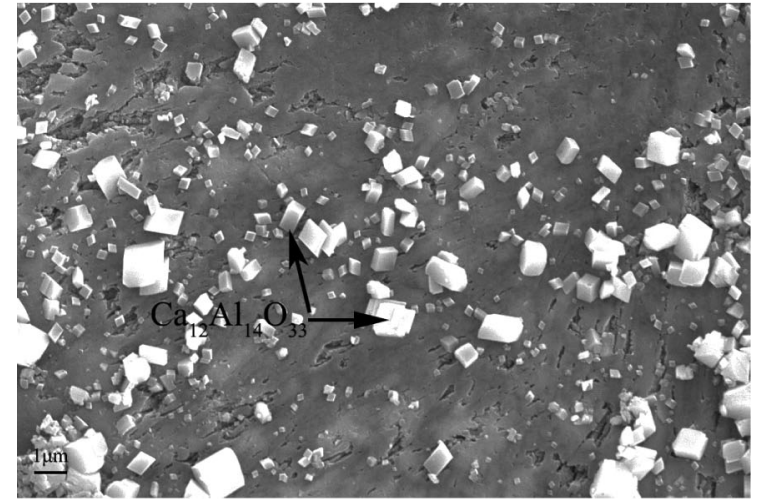

(a) $540^{\circ} \mathrm{C}$, Sample 1

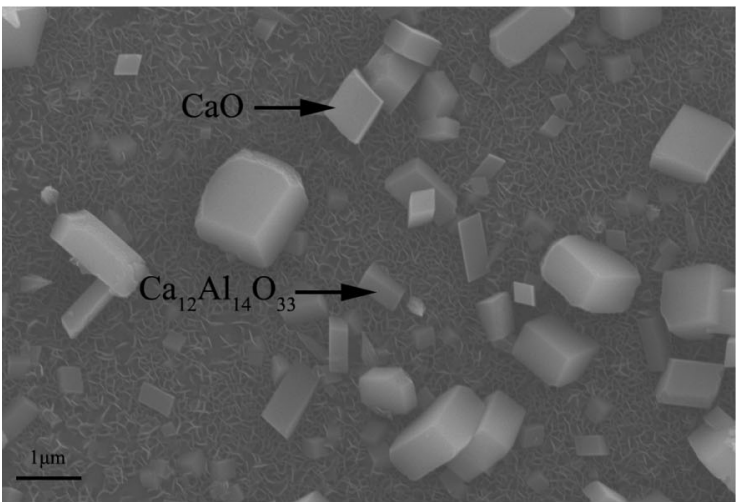

(b) $610^{\circ} \mathrm{C}$, Sample 1

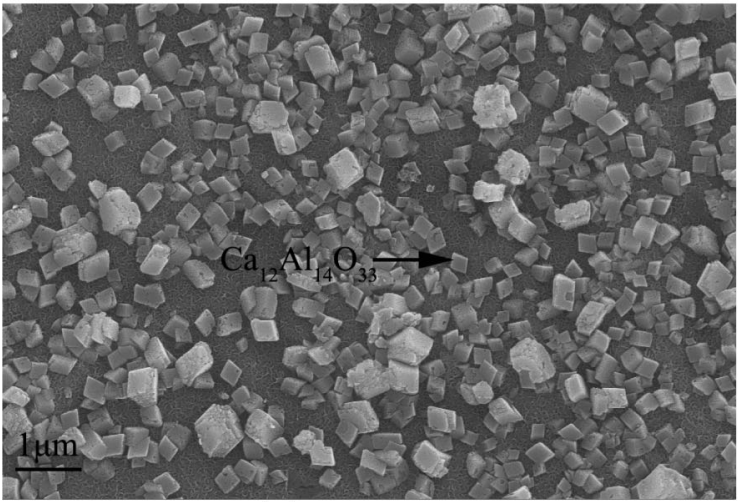

(c) $540{ }^{\circ} \mathrm{C}$, Sample 2

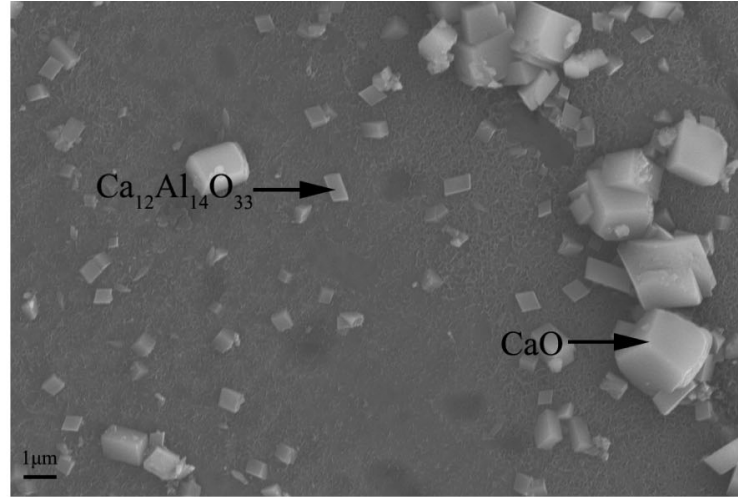

(d) $630^{\circ} \mathrm{C}$, Sample 2

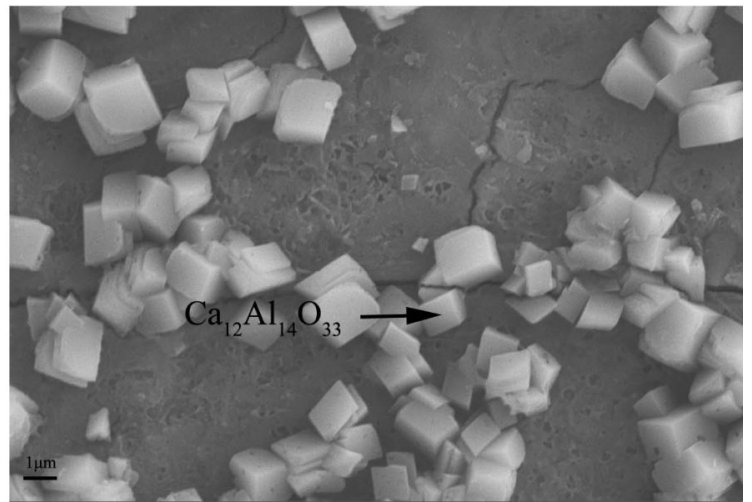

(e) $610{ }^{\circ} \mathrm{C}$, Sample 3

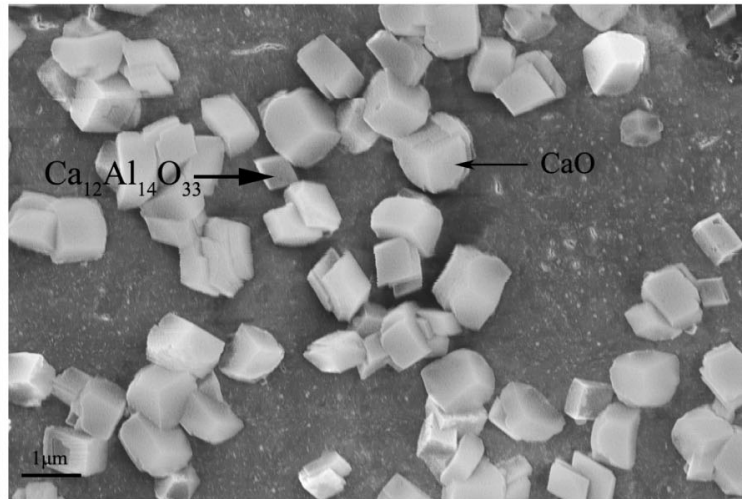

(f) $630^{\circ} \mathrm{C}$, Sample 3

Fig. 5-FE-SEM micrographs for Sample $1(a)$ and $(b)$, Sample $2(c)$ and $(d)$, and Sample $3(e)$ and $(f)$, heat treated at different temperatures. 


$$
\alpha_{T}=\frac{\int_{T_{0}}^{T}(\mathrm{~d} H / \mathrm{d} T) \mathrm{d} T}{\int_{T_{0}}^{T_{\mathrm{e}}}(\mathrm{d} H / \mathrm{d} T) \mathrm{d} T},
$$

where $T, T_{0}$, and $T_{\mathrm{e}}$ represent the instantaneous, onset, and end crystallization temperature, respectively, and $\mathrm{d} H / \mathrm{d} T$ represents the heat flow rate measured by DSC. The values of $\alpha_{T}$ at various heating rates as a function of temperature are shown in Figures 7 and 8 for the first and the second crystallization events for samples 1, 2, and 3 .

The Matusita-Sakka model ${ }^{[26-28]}$ has been applied in crystallization kinetics analysis for various kinds of glasses, ${ }^{[29-33]}$ and it was also employed to investigate the non-isothermal crystallization kinetics for traditional mold fluxes. ${ }^{[13]}$ The main equation for the model is as follows:

$$
\ln [-\ln (1-\alpha)]=-n \ln \beta-1.052 \frac{m E_{\mathrm{G}}}{R T}+\text { const, }
$$

where $\alpha$ is the volume fraction of crystals, $\beta$ is the heating rate, $E_{\mathrm{G}}$ is the effective activation energy for crystallization, $n$ and $m$ are constants associated with the crystallization mechanism.

There are two different relations between $n$ and $m$, depending on the saturation of nuclei during the non-isothermal process:

i. If a large number of nuclei exists in the glass, i.e., for a well nucleated sample, it is possible to neglect the nucleation rate and then $n=m$;

ii. If the nucleation proceeds with constant rate and the nucleation frequency cannot be ignored then $n=m+1 .{ }^{[26-28]}$

Table III lists the values of $n$ and $m$ as well as the corresponding crystallization mechanism. ${ }^{[32]}$ Samples investigated in the present work were quenched after melting and no preheating was performed before DSC measurements. Therefore, no nuclei should exist in the glassy samples prior to experiments and $n$ should be equal to $m+1$.

Values for $n$ can be determined by the Ozawa equation at constant temperature from DSC curves for different heating rates ${ }^{[34]}$ :

$$
\left.\frac{d(\ln [-\ln (1-\alpha)])}{d(\ln \beta)}\right|_{T}=-n .
$$

This equation can be obtained from Eq. [2] by assuming $E_{\mathrm{G}}$ and $m$ is constant during the overall crystallization process.

Three temperatures for each sample were selected to calculate the $n$ values by plotting $\ln [-\ln (1-\alpha)]$ as a function of $\ln \beta$. Ozawa plots for the first and the second crystallization events are shown in Figures 9 and 10, respectively.

The values for $n$ were obtained by averaging values for three different temperatures; see Table IV, where the $m$ values are also shown. These values should be combined with the morphologies investigated by FE-SEM to determine the crystallization mechanisms. As can be seen at Figure 5, $\mathrm{Ca}_{12} \mathrm{Al}_{14} \mathrm{O}_{33}$ precipitated mainly as plate-like crystals, indicating two-dimensional crystallization, for any $\mathrm{w}(\mathrm{CaO}) / \mathrm{w}\left(\mathrm{Al}_{2} \mathrm{O}_{3}\right)$ ratio.
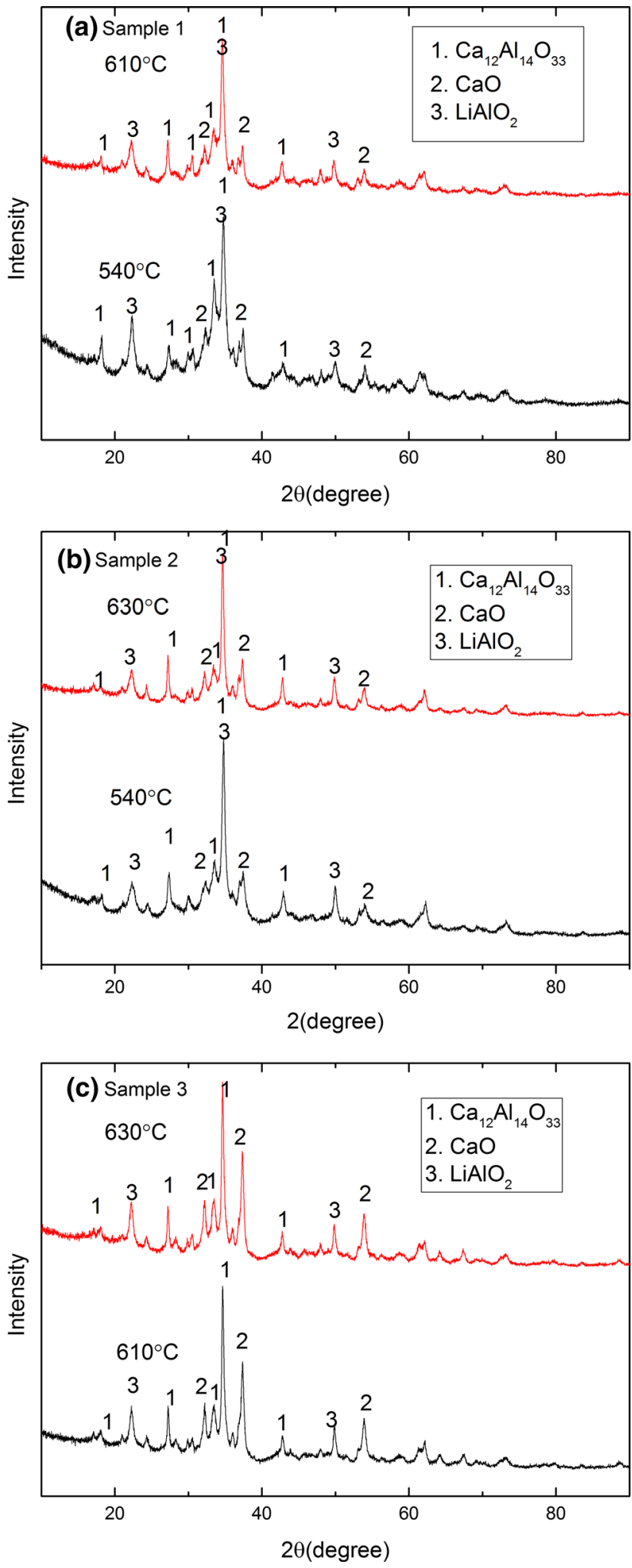

Fig.6-XRD patterns for samples heated at different temperatures (a): Sample 1; (b): Sample 2; (c): Sample 3. 
Regarding $\mathrm{CaO}$ crystallization, it can be seen at Figure 5, it is two-dimensional for Sample 1, and three-dimensional for samples 2 and 3 .

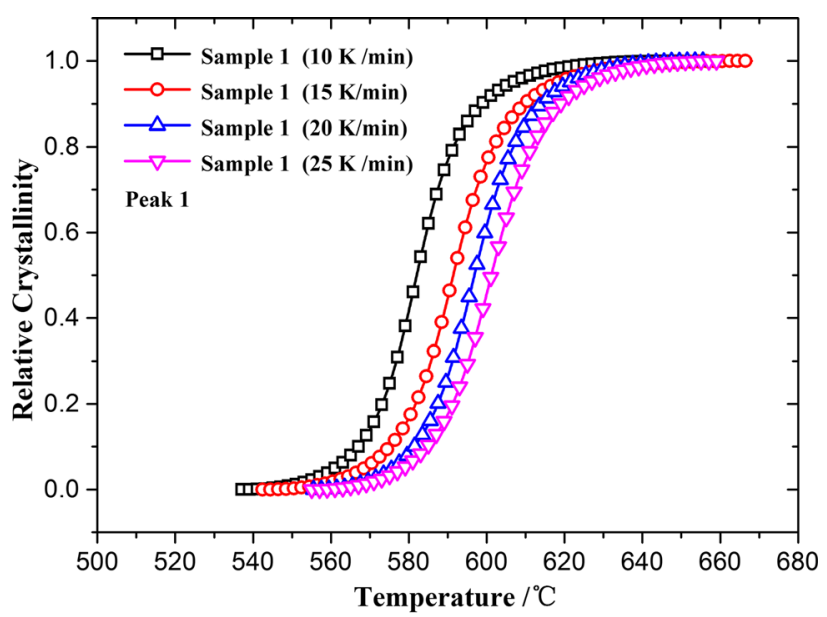

(a)

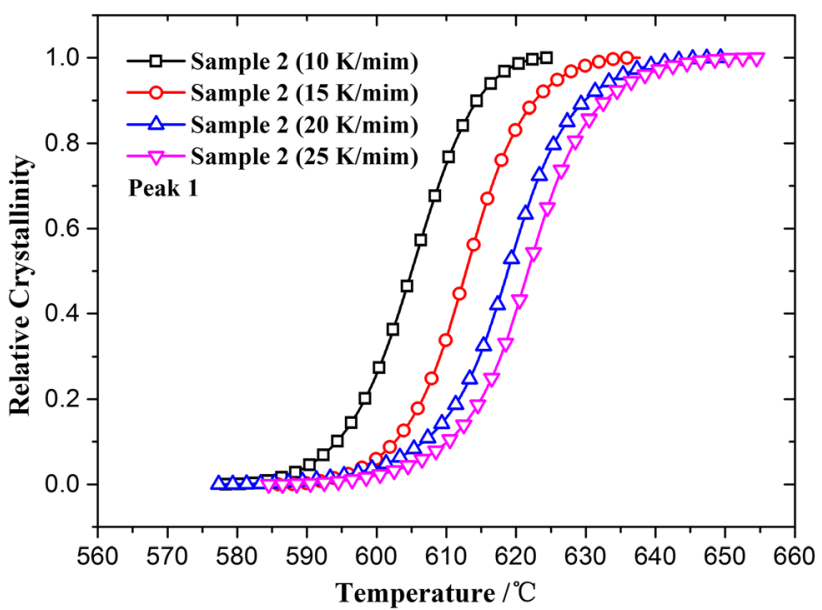

(b)

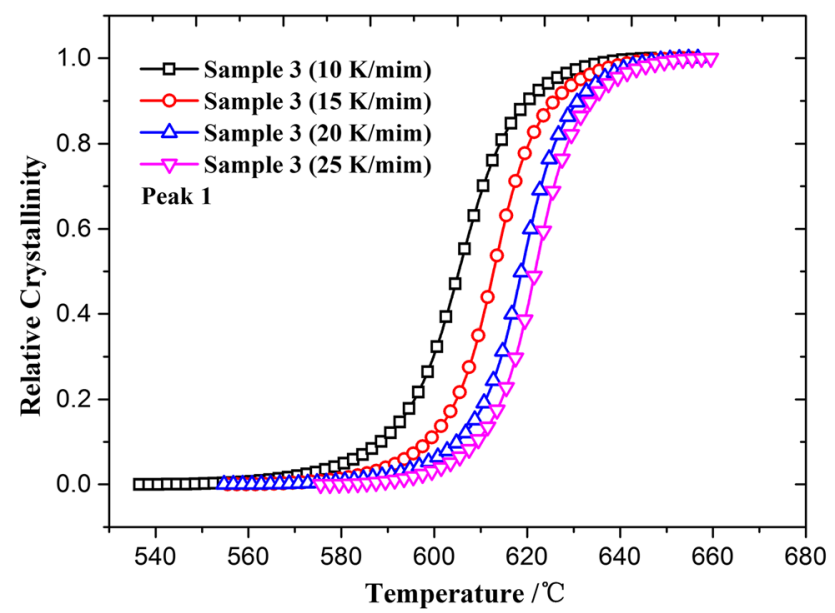

(c)

Fig. 7-Relative crystallinity of $\mathrm{Ca}_{12} \mathrm{Al}_{14} \mathrm{O}_{33}$ as a function of temperature for (a) Sample 1, (b) Sample 2, and (c) Sample 3.
Regarding the first crystallization event for Sample 1 $\left(\mathrm{w}(\mathrm{CaO}) / \mathrm{w}\left(\mathrm{Al}_{2} \mathrm{O}_{3}\right)\right.$ of 0.9$), n$ value is close to 2 (Table IV). This indicates bulk crystallization, and diffusion-controlled two-dimensional growth with

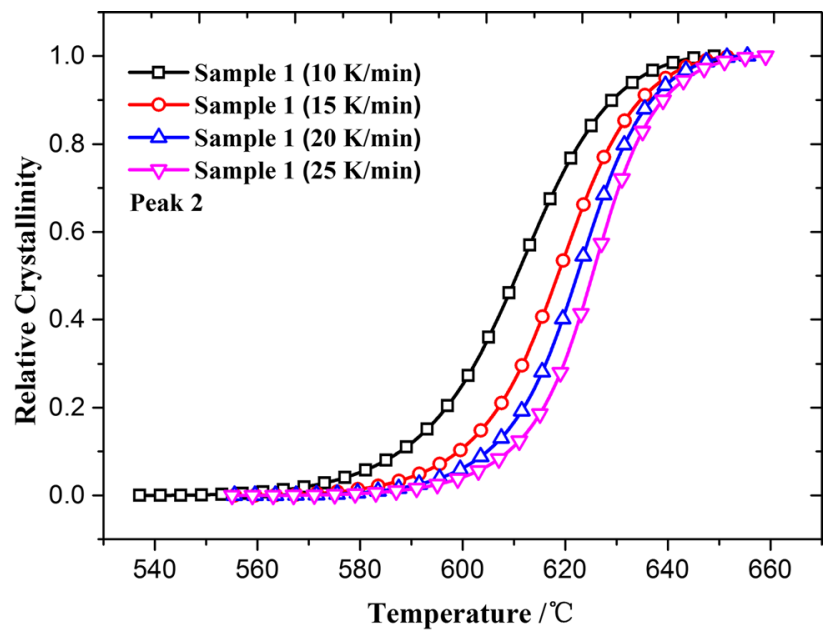

(a)

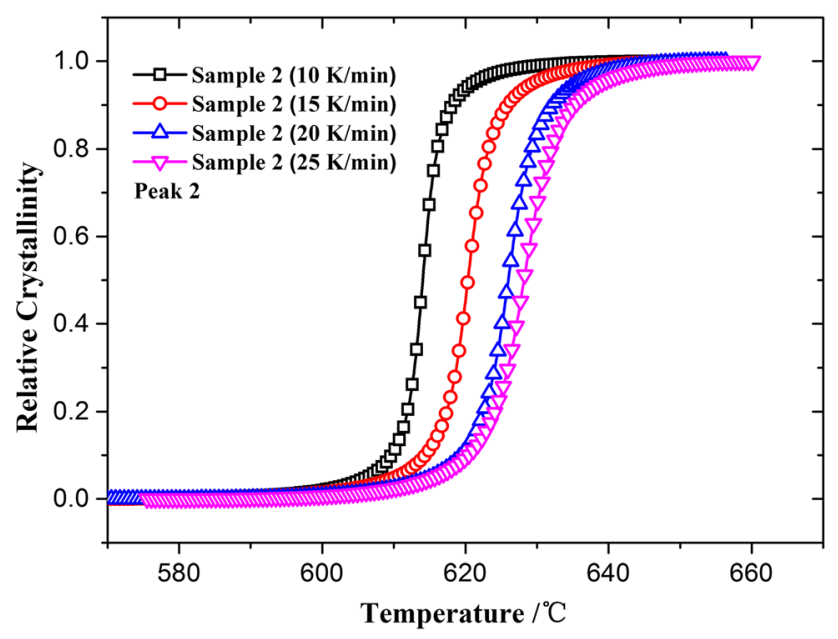

(b)

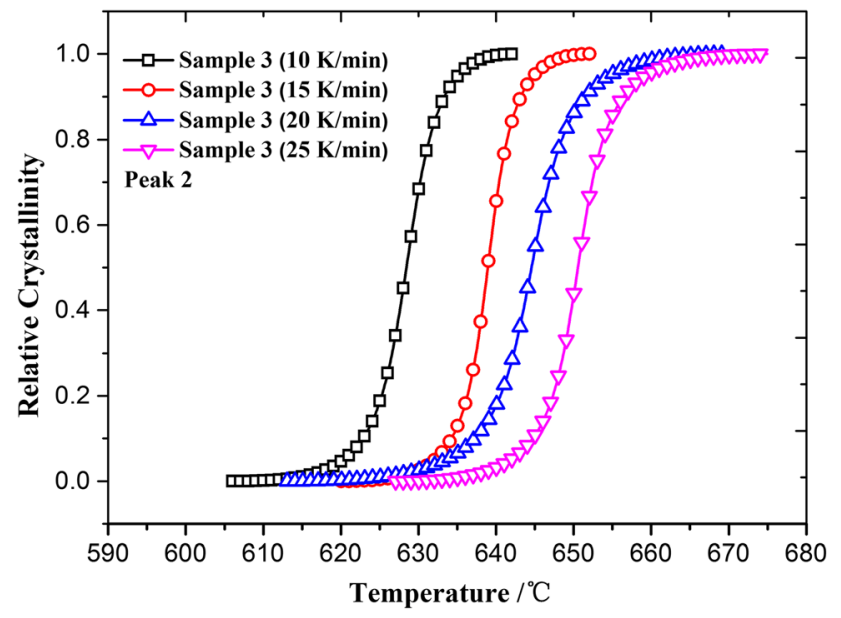

(c)

Fig. 8-Relative crystallinity of $\mathrm{CaO}$ as a function of temperature for (a) Sample 1, (b) Sample 2, and (c) Sample 3, respectively. 
Table III. Avrami Parameters $n$ and $\boldsymbol{m}$ Corresponding to Different Crystallization Mechanisms ${ }^{[32]}$

\begin{tabular}{lcc}
\hline Crystallization Mechanism & $n$ & $m$ \\
\hline Bulk crystallization with an increasing number of nuclei (the number of nuclei is inversely proportional to the heating rate) & 4 \\
Three-dimensional growth & 3 & 3 \\
Two-dimensional growth & 2 & 2 \\
One-dimensional growth & 1 \\
Bulk crystallization with an increasing number of nuclei (the number of nuclei is inversely proportional to the heating rate with \\
crystal growth rate proportional to $t^{-0.5}$ ), diffusion controlled & 2.5 & 1.5 \\
Three-dimensional growth & 2 & 1 \\
Two-dimensional growth & 1.5 & 0.5 \\
One-dimensional growth & 1 & 1 \\
Surface crystallization & & \\
\hline
\end{tabular}

increasing number of nuclei during heating, with growth rate proportional to $t^{-0.5}$, according to Table III. For samples 2 and $3\left(\mathrm{w}(\mathrm{CaO}) / \mathrm{w}\left(\mathrm{Al}_{2} \mathrm{O}_{3}\right)\right.$ of 1.0 and 1.1 , respectively), $n$ values for the first crystallization event are close to 3, which indicates the crystallization mechanism of bulk crystallization of two-dimensional growth with increasing number of nuclei. Thus, the calculated Avrami parameters are coherent with the SEM images, for $\mathrm{Ca}_{12} \mathrm{Al}_{14} \mathrm{O}_{33}$ precipitation.

The second crystallization event is the precipitation of $\mathrm{CaO}$. The $n$ value for Sample 1 is close to 2, indicating that the crystallization mechanism is diffusion-controlled two-dimensional growth with increasing number of nuclei during heating. This agrees with the two-dimensional particle identified with electron microscope at a higher temperature, Figure 5(b). Regarding samples 2 and 3 , the $n$ values are close to 4 , indicating that the crystallization mechanism is bulk crystallization, with three-dimensional growth with increasing number of nuclei during heating, according to Table III. The $n$ value 4 agrees with the electron microscope observation, Figures 5(d) and (f).

According to Eq. [2], $m E_{\mathrm{G}} / n$ can be determined by plotting $\ln \beta$ in function of $1 / T$ at a particular relative crystallinity using multiple DSC curves:

$$
\left.\frac{d(\ln \beta)}{d\left(\frac{1}{T}\right)}\right|_{\alpha}=-1.052 \frac{m E_{\mathrm{G}}}{n R} .
$$

Figures 11 and 12 show plots of $\ln \beta$ against $1000 / T$ at $\alpha=0.2,0.4,0.6$, and 0.8 for crystallization of $\mathrm{Ca}_{12} \mathrm{Al}_{14} \mathrm{O}_{33}$ and $\mathrm{CaO}$, respectively. With the Avrami parameters $m$ and $n, E_{\mathrm{G}}$ can be determined for each relative crystallinity value.

Figures 13 and 14 show activation energy of crystallization in function of relative crystallinity, for crystallization of $\mathrm{Ca}_{12} \mathrm{Al}_{14} \mathrm{O}_{33}$ and $\mathrm{CaO}$. $E_{\mathrm{G}}$ decreases with the increase of $\mathrm{w}(\mathrm{CaO}) / \mathrm{w}\left(\mathrm{Al}_{2} \mathrm{O}_{3}\right)$ ratio for the first crystallization event, which is the most important one (in terms of energy liberated and amount of crystals). The activation energy for crystallization reflects the energy barrier for crystallization. Thus, it can be concluded that mold fluxes crystallization is enhanced when increasing $\mathrm{w}(\mathrm{CaO}) / \mathrm{w}\left(\mathrm{Al}_{2} \mathrm{O}_{3}\right)$ ratio.
Crystal growth rate $U$ in function of Gibbs free energy change for crystallization and kinetic activation energy is given as ${ }^{[35]}$ :

$$
\left.U=U_{0} \exp -E / R T\right)[1-\exp (-\Delta G / R T)]
$$

where $U_{0}$ is the pre-exponential factor, $\Delta G$ is the Gibbs free energy change for crystallization, and $E$ is the activation energy for mass transfer across to crystal-liquid interface. At relatively low temperatures, the temperature dependence of the term $[1-\exp (-\Delta G /$ $R T)$ ] is negligibly small compared with that of $\exp (-E / R T)$. Therefore, $E$ may be considered as the activation energy of crystal growth. According to the Matusita-Sakka model, ${ }^{[26-28]}$ nucleation proceeds between glass transition temperature and onset temperature for a DSC peak. Therefore, DSC peaks can be attributed only to crystal growth.

Since activation energy of crystallization is mainly determined by mass transfer across to the interface, the diffusion coefficient of glassy fluxes could be employed to interpret the composition dependence of activation energy obtained in this work. There is very few information on diffusion coefficient of glassy mold fluxes in literature. Viscosity data of slag melts could be employed to qualitatively reflect the composition dependence of diffusion coefficient considering the Stokes-Einstein equation ${ }^{[36]}$.

$$
D=\frac{k T}{6 \pi r \eta}
$$

where $D$ is the diffusion coefficient of the ion in the slag, $T$ is the absolute temperature, $k$ is the Boltzmann constant, $r$ is the radius of the ion in the slag. From the above equation, diffusion coefficient of ions in slag is inversely proportional to the viscosity of the slag. Kim and Sohn ${ }^{[37]}$ measured viscosity of calcium-aluminate mold slag containing $\mathrm{Na}_{2} \mathrm{O}$. Higher $w(\mathrm{CaO}) /$ $\mathrm{w}\left(\mathrm{Al}_{2} \mathrm{O}_{3}\right)$ ratios at fixed $\mathrm{B}_{2} \mathrm{O}_{3}$ content decreased the viscosity of fluxes; the present fluxes have compositions similar to these ones. With the increase of $\mathrm{w}(\mathrm{CaO}) / \mathrm{w}\left(\mathrm{Al}_{2} \mathrm{O}_{3}\right)$ ratio the viscosity decreases, i.e., the diffusion coefficient of ions increases. Accordingly, the barrier for diffusion, $E$, decreases with increasing $\mathrm{w}(\mathrm{CaO}) / \mathrm{w}\left(\mathrm{Al}_{2} \mathrm{O}_{3}\right)$ ratio. 
On the other hand, the structural information of glassy mold fluxes could also be used to explain the composition dependence for crystallization. The structures of $\mathrm{CaO}-\mathrm{Al}_{2} \mathrm{O}_{3}-\mathrm{B}_{2} \mathrm{O}_{3}$ and $\mathrm{CaO}-\mathrm{Al}_{2} \mathrm{O}_{3}-\mathrm{B}_{2} \mathrm{O}_{3}-\mathrm{Na}_{2} \mathrm{O}$ were investigated using Raman spectroscopy. ${ }^{[37,38]}$ With the increase of $\mathrm{w}(\mathrm{CaO}) / \mathrm{w}\left(\mathrm{Al}_{2} \mathrm{O}_{3}\right)$ ratio, aluminate network in mold fluxes was modified; the structural units

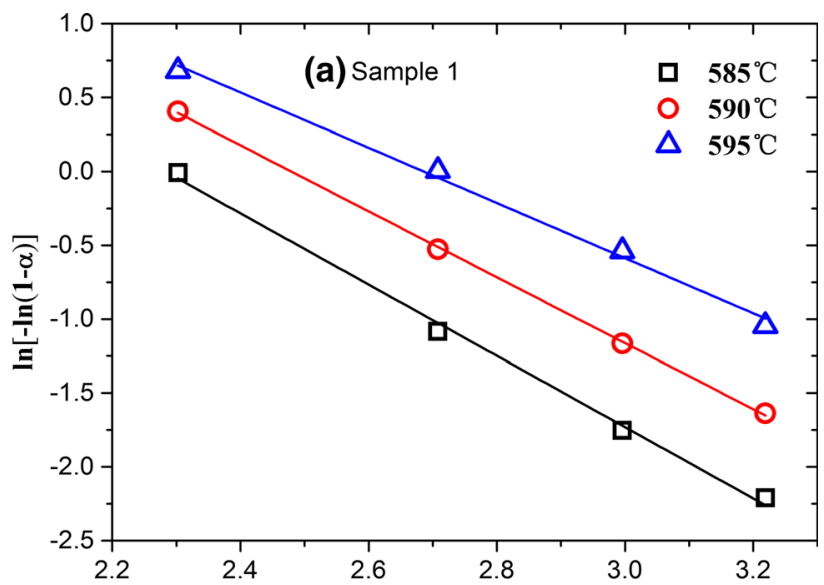

$\ln \beta$
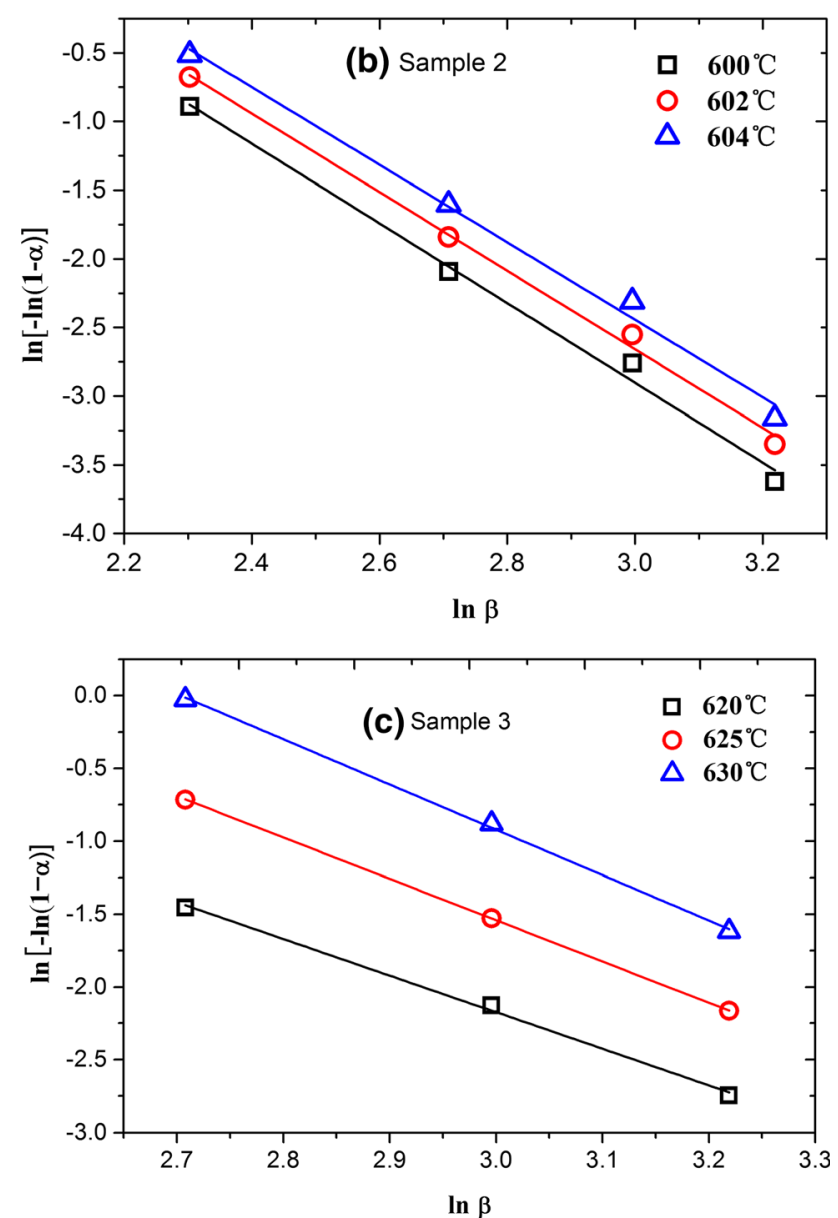

Fig. 9-Ozawa plots for the crystallization of $\mathrm{Ca}_{12} \mathrm{Al}_{14} \mathrm{O}_{33}$ for $(a)$ Sample 1, (b) Sample 2, and (c) Sample 3, respectively. became simpler and the degree of polymerization for aluminate network for mold fluxes was reduced. Thus, when increasing the $\mathrm{w}(\mathrm{CaO}) / \mathrm{w}\left(\mathrm{Al}_{2} \mathrm{O}_{3}\right)$ ratio, viscosity should decrease and diffusion coefficient should increase, reducing energy barrier for ions transfer from bulk to glass-crystal interface.
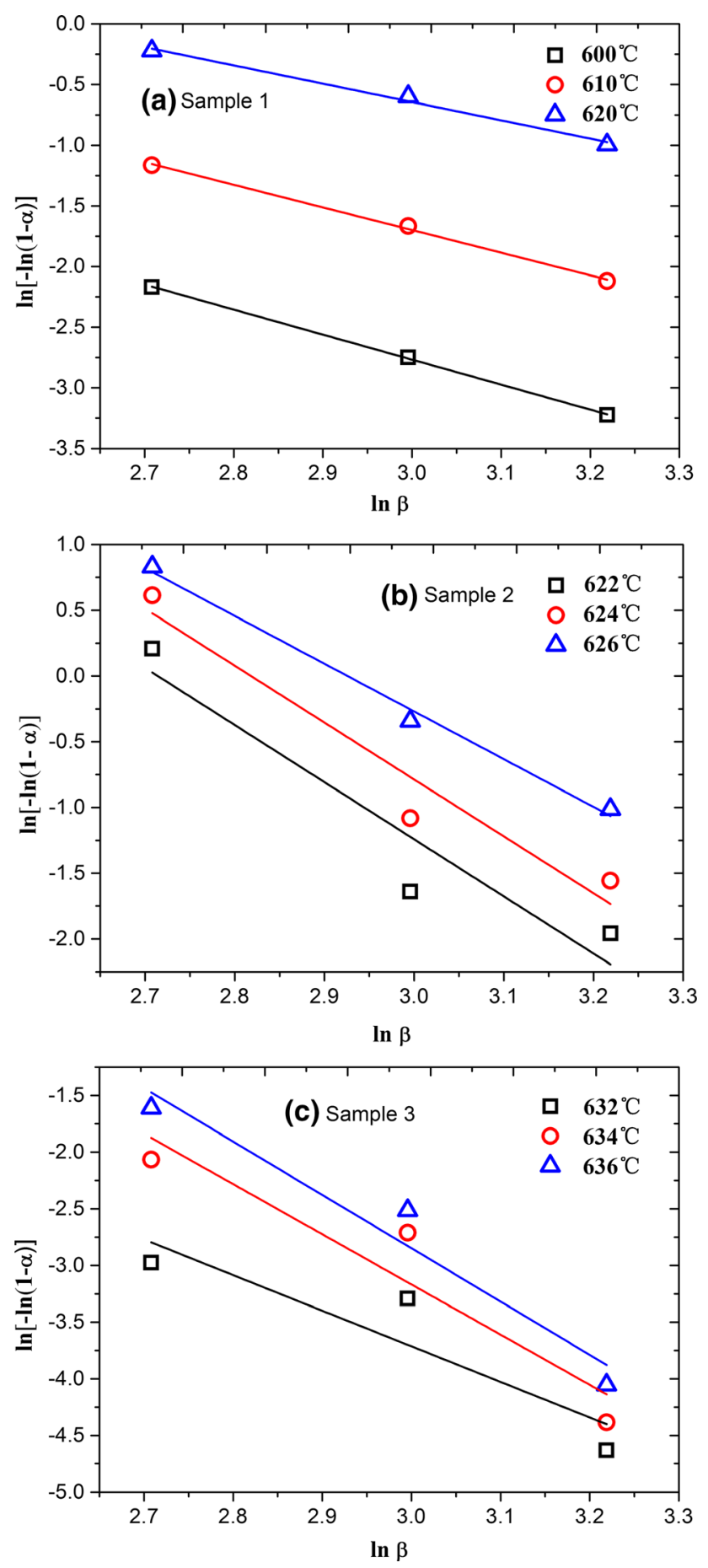

Fig. 10 - Ozawa plots for the crystallization of $\mathrm{CaO}$ for (a) Sample 1, (b) Sample 2, and (c) Sample 3, respectively. 
Table IV. Calculated Avrami Parameters for Devitrification

(Crystallization Event 1: $\mathrm{Ca}_{12} \mathrm{Al}_{14} \mathrm{O}_{33}$ Precipitation; Crystallization Event 2: CaO Precipitation)

\begin{tabular}{lccc}
\hline Sample & Crystallization Event & $n$ & $m$ \\
\hline 1 & 1 & 2.17 & 1.17 \\
& 2 & 1.80 & 0.80 \\
2 & 1 & 2.86 & 1.86 \\
& 2 & 4.10 & 3.10 \\
3 & 1 & 3.02 & 2.02 \\
& 2 & 4.09 & 3.09 \\
\hline
\end{tabular}

\section{CONCLUSIONS}

The crystallization kinetics of glassy $\mathrm{CaO}-\mathrm{Al}_{2} \mathrm{O}_{3}-$ $\mathrm{B}_{2} \mathrm{O}_{3}-\mathrm{Na}_{2} \mathrm{O}-\mathrm{Li}_{2} \mathrm{O}$ fluoride-free mold fluxes during heating was investigated. The following conclusions can be drawn:

(1) For the first crystallization event $-\mathrm{Ca}_{12} \mathrm{Al}_{14} \mathrm{O}_{33}$ precipitation - for Sample $1\left(\mathrm{w}(\mathrm{CaO}) / \mathrm{w}\left(\mathrm{Al}_{2} \mathrm{O}_{3}\right)\right.$ of $0.9), n$ value is close to 2 . This indicates bulk crystallization, and diffusion-controlled two-dimensional growth with increasing number of nuclei during heating, with growth rate proportional to $t^{-0.5}$. For Sample 2 and for Sample $3(\mathrm{w}(\mathrm{CaO} / /$ $\mathrm{w}\left(\mathrm{Al}_{2} \mathrm{O}_{3}\right)$ of 1.0 and 1.1 , respectively), $n$ values are close to 3, which indicates the crystallization mechanism of bulk crystallization of two-dimensional growth with increasing number of nuclei. The calculated Avrami parameters are coherent with the SEM images.

(2) For the second crystallization event- $\mathrm{CaO}$ precipitation-for Sample 1 the $n$ value is close to 2, indicating bulk crystallization, with diffusion-controlled two-dimensional growth with increasing number of nuclei during heating. Regarding samples 2 and 3, the $n$ values are close to 4 , indicating that the crystallization mechanism is bulk crystallization, with three-dimensional growth with increasing number of nuclei during heating. The calculated Avrami parameters are coherent with the SEM images.

(3) The most important event (in terms of energy liberated and amount of crystals) is $\mathrm{Ca}_{12} \mathrm{Al}_{14} \mathrm{O}_{33}$ precipitation. For this event, the effective activation energy for crystallization, $E_{\mathrm{G}}$, decreases with the increase of $\mathrm{w}(\mathrm{CaO}) / \mathrm{w}\left(\mathrm{Al}_{2} \mathrm{O}_{3}\right)$ ratio. The activation energy for crystallization reflects the energy barrier for crystallization. Thus, it can be concluded that mold fluxes crystallization is enhanced when increasing the $\mathrm{w}(\mathrm{CaO}) / \mathrm{w}\left(\mathrm{Al}_{2} \mathrm{O}_{3}\right)$ ratio.

(4) The composition dependence of activation energy of crystallization can be interpreted by correlating crystallization with viscosity and structure of mold fluxes. Thus, when increasing the $\mathrm{w}(\mathrm{CaO}) / \mathrm{w}\left(\mathrm{Al}_{2} \mathrm{O}_{3}\right)$ ratio, viscosity should decrease and diffusion coefficient should increase, reducing energy barrier for
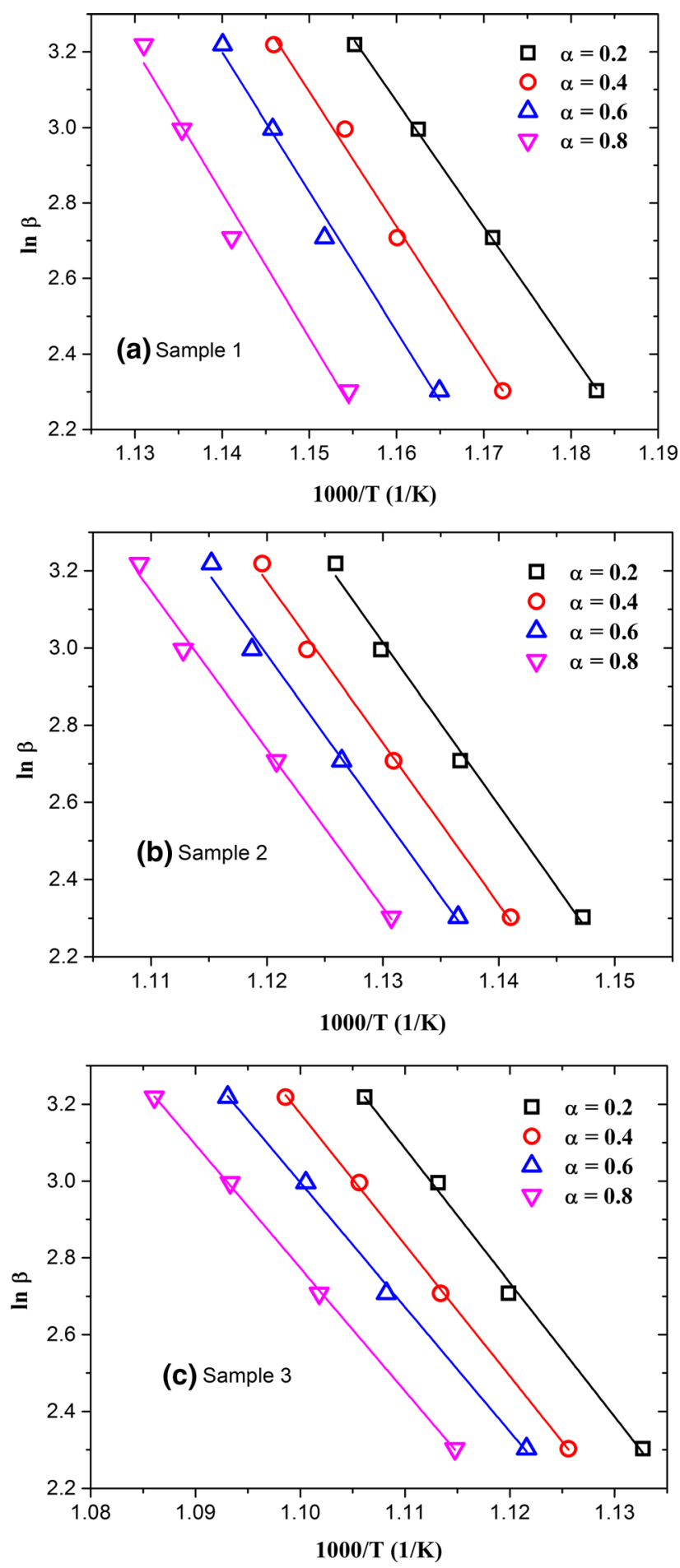

Fig. $11-\ln \beta$ as a function of $1000 / T$ for the crystallization of $\mathrm{Ca}_{12} \mathrm{Al}_{14} \mathrm{O}_{33}$ for (a) Sample 1, (b) Sample 2, and (c) Sample 3.

ions transfer from bulk to glass-crystal interface, due to reduction of degree of polymerization of aluminate network. 

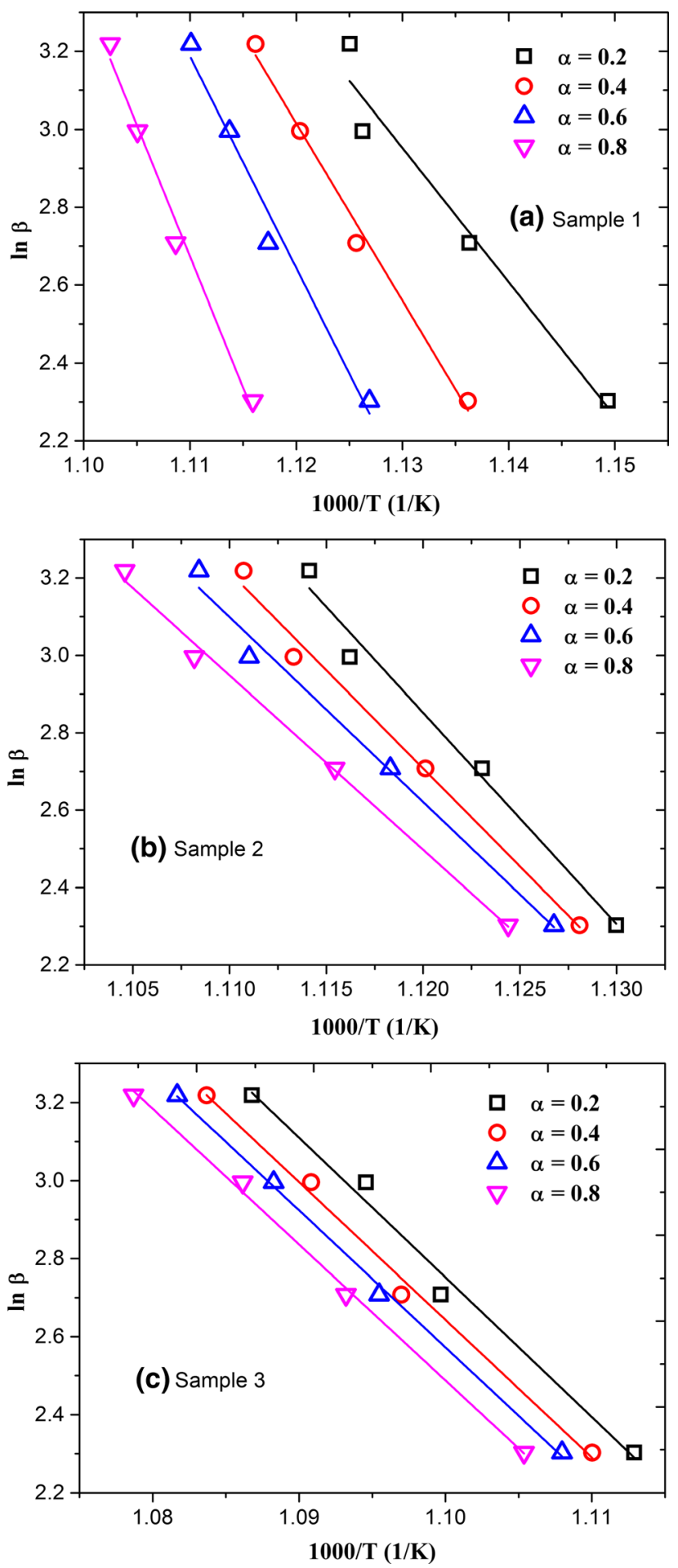

Fig. $12-\ln \beta$ as a function of $1000 / T$ for the crystallization of $\mathrm{CaO}$ for (a) Sample 1, (b) Sample 2, and (c) Sample 3, respectively.

\section{ACKNOWLEDGEMENTS}

Open access funding provided by University of Oulu including Oulu University Hospital. Financial support from Natural Science Foundation of China (NSFC Contract No. 51774026), from Academy of Finland

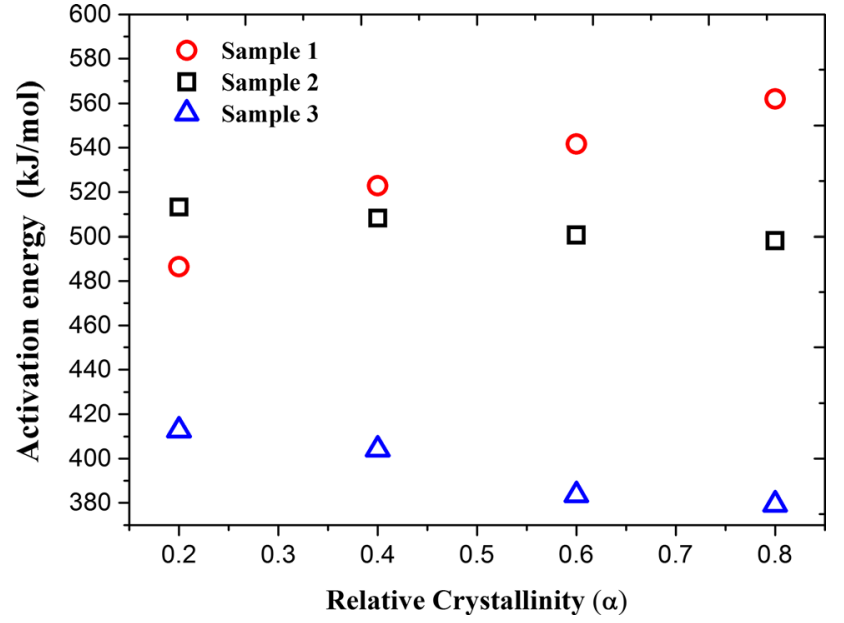

Fig. 13-Activation energy of crystallization in function of relative crystallinity, for the crystallization of $\mathrm{Ca}_{12} \mathrm{Al}_{14} \mathrm{O}_{33}$, for Samples 1, 2, and 3.

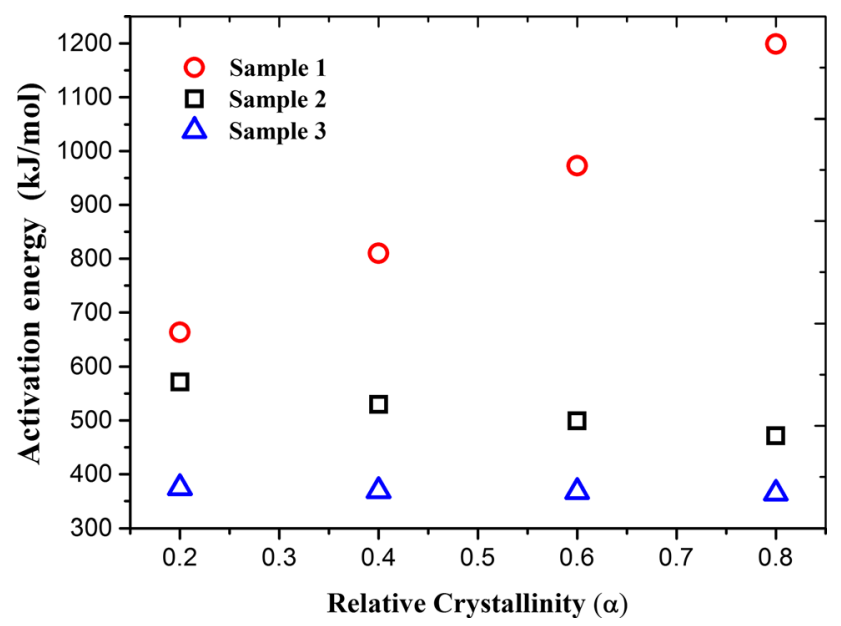

Fig. 14-Activation energy of crystallization as a function of relative crystallinity, for the crystallization of $\mathrm{CaO}$, for Samples 1, 2, and 3 .

for Genome of Steel Grant (No. 311934), and from Coordenação de Aperfeiçoamento de Pessoal de Nivel Superior - Brasil (CAPES, Finance Code 001) is gratefully acknowledged.

\section{OPEN ACCESS}

This article is licensed under a Creative Commons Attribution 4.0 International License, which permits use, sharing, adaptation, distribution and reproduction in any medium or format, as long as you give appropriate credit to the original author(s) and the source, provide a link to the Creative Commons licence, and indicate if changes were made. The images or other third party material in this article are included in the article's Creative Commons licence, unless indicated otherwise in a credit line to the material. If material is 
not included in the article's Creative Commons licence and your intended use is not permitted by statutory regulation or exceeds the permitted use, you will need to obtain permission directly from the copyright holder. To view a copy of this licence, visit http://creativec ommons.org/licenses/by/4.0/.

\section{REFERENCES}

1. K.C. Mills, A.B. Fox, Z. Li, and R.P. Thackray: Ironmak. Steelmak., 2005, vol. 32, pp. 26-34.

2. K. Tsutsumi, T. Nagasaka, and M. Hino: ISIJ Int., 1999, vol. 39, pp. $1150-59$.

3. J.W. Cho, T. Emi, H. Shibata, and M. Suzuki: ISIJ Int., 1998, vol. 38 , pp. 834-42.

4. S. He, Z. Li, Z. Chen, T. Wu, and Q. Wang: Steel Res. Int., 2019, vol. 90 , p. 1800424.

5. J.L. Li, B.W. Kong, B. Galdino, J.F. Xu, K.C. Chou, Q.C. Liu, and Q.F. Shu: Steel Res. Int., 2017, vol. 88 (9), p. 1600485.

6. L. Zhou, H. Li, W. Wang, D. Xiao, L. Zhang, and J. Yu: Metall. Mater. Trans. B, 2018, vol. 49B, pp. 2232-40.

7. L. Zhang and W. Wang: ISIJ Int., 2019, vol. 59, pp. 1041-48.

8. J. Yang, J. Zhang, Y. Sasaki, O. Ostrovski, C. Zhang, D. Cai, and Y. Kashiwaya: Metall. Mater. Trans. B, 2017, vol. 48B, pp. 201777.

9. F. Shahbazian, D. Sichen, K.C. Mills, and S. Seetharaman: Ironmak. Steelmak., 1999, vol. 26, p. 193.

10. A.B. Fox, K.C. Mills, D. Lever, C. Bezerra, C. Valadares, I. Unamuno, J.J. Laraudogoitia, and J. Gisby: ISIJ Int., 2005, vol. 45 , p. 1051.

11. H. Nakada and K. Nagata: ISIJ Int., 2006, vol. 46, p. 441.

12. M. Hayashi, T. Watanabe, H. Nakada, and K. Nagata: ISIJ Int., 2006, vol. 46, pp. 1805-09.

13. Z. Wang, Q.F. Shu, and K.C. Chou: Metall. Mater. Trans. B, 2013, vol. 44B, pp. 606-13.

14. M.D. Seo, C.B. Shi, J.W. Cho, and S.H. Kim: Metall. Mater. Trans. B, 2014, vol. 45B, pp. 1874-86.

15. M.D. Seo, C.B. Shi, H. Wang, J.W. Cho, and S.H. Kim: J. Non-Cryst. Solids, 2015, vol. 412, pp. 58-65.

16. M.D. Seo, C.B. Shi, J.Y. Baek, J.W. Cho, and S.H. Kim: Metall. Mater. Trans. B, 2015, vol. 46B, pp. 2374-83.
17. Y. Kashiwaya, C.E. Cicutti, A.W. Cramb, and K. Ishii: ISIJ Int., 1998, vol. 38, pp. 348-56.

18. J.L. Klug, R. Hagemann, N.C. Heck, A.C. Vilela, H.P. Heller, and P.R. Scheller: Steel Res. Int., 2012, vol. 83, pp. 1186-93.

19. Q.F. Shu, Z. Wang, J.L. Klug, K.C. Chou, and P.R. Scheller: Steel Res. Int., 2013, vol. 84, pp. 1138-45.

20. L. Zhou, W. Wang, D. Huang, J. Wei, and J. Li: Metall. Mater. Trans. B, 2012, vol. 43, pp. 925-36.

21. H.G. Ryu, Z.T. Zhang, J.W. Cho, G.H. Wen, and S. Sridhar: ISIJ Int., 2010, vol. 50, pp. 1142-50.

22. Z. Li, R. Thackray, and K.C Mills: In VII International Conference on Molten Slags Fluxes and Salts, Cape Town, South Africa, 2004.

23. H. Mizuno, H. Esaka, K. Shinozuka, and M. Tamura: ISIJ Int., 2008, vol. 48, pp. 277-85.

24. J.L. Li, B.J. Yan, Q.F. Shu, and K.C. Chou: Metall. Mater. Trans. B, 2015, vol. 46B, pp. 2458-69.

25. Z. Wang, Q.F. Shu, and K.C. Chou: ISIJ Int., 2015, vol. 55, pp. $709-16$.

26. K. Matusita, T. Komatsu, and R. Yokota: J. Mater. Sci., 1984, vol. 19, pp. 291-96.

27. K. Matusita and S. Sakka: Phys. Chem. Glasses, 1979, vol. 20, pp. 81-84.

28. K. Matusita and S. Sakka: J. Non-Cryst. Solids, 1980, vol. 38, pp. $741-46$.

29. D.W. Henderson and D.G. Ast: J. Non-Cryst. Solids, 1984, vol. 64 , pp. 43-70.

30. A.A.S. Lopes, R.S. Soares, M.M.A. Lima, and R.C.C. Monteiro: J. Appl. Phys., 2014, vol. 115, p. 043516.

31. A.M. Rodrigues, J.M.R. Mercury, V.S. Leal, and A.A. Cabral: $J$. Non-Cryst. Solids, 2013, vol. 362, pp. 114-19.

32. I.W. Donald: J. Non-Cryst. Solids, 2004, vol. 345, pp. 120-26.

33. Y. Cheng, H.N. Xiao, W.M. Guo, and W.M. Guo: Ceram. Int., 2007, vol. 33, pp. 1341-47.

34. T. Ozawa: Polym., 1971, vol. 12, pp. 150-58.

35. R.J. Kirkpatrick: Am. Miner., 1975, vol. 60, pp. 798-814.

36. C. Orrling and A.W. Cramb: Metall. Mater. Trans. B, 2000, vol. 31B, pp. 403-06.

37. G.H. Kim and I. Sohn: Metall. Mater. Trans. B, 2014, vol. 45B, pp. 86-95.

38. Q.F. Shu, P.F. Li, X. Zhang, and K.C. Chou: Metall. Mater. Trans. B, 2016, vol. 47B, pp. 3527-32.

Publisher's Note Springer Nature remains neutral with regard to jurisdictional claims in published maps and institutional affiliations. 